\title{
TAM-Full Object-Verb Order in the Mbam languages of Cameroon*
}

\author{
Maarten Mous
}

Leiden University Centre of Linguistics

\begin{abstract}
Nen and Nyokon are unique among the Bantu languages in allowing full nominal objects between the tense/aspect marker and the verb. Despite the fact that the two languages are neighbours and related they make different use of this positional option. In Nen the position is the default one for objects and the post-verbal position renders an object discrete and suitable for quantified objects and for contrast. In Nyokon the position before the verb is functionally equivalent to the one after the verb. The difference is related to the fact that Nyokon allows the preverbal object only in certain tenses whereas in Nen it is not restricted. But contrasted objects in Nyokon too appear after the verb. There is a construction in which both positions are filled with a constituent. This construction is modelled on a secondary predication construction.
\end{abstract}

\section{Introduction}

Bantu languages are predominantly SVO with the possibility of different positions of $\mathrm{S}$ and $\mathrm{O}$ for pragmatic reasons. The two Bantu languages that $\mathrm{I}$ concentrate on, Nyokon and Nen, are different in this respect. Both allow for a full NP object between the subject plus tense/aspect marking and the verb. The pragmatic properties of object placement in Nen have been discussed in Mous (1996) but I repeat and expand on it here using the excellent documentation of the language by Dugast and in particular her text collection (Dugast 1975), referred to as DC in this article, and a more recent study (Kendall 2007) containing two of Dugast's texts, fully glossed. The data on Nyokon come from a period of two weeks of intensive cooperation in Yaounde with Viviane Kigno, a student of linguistics and mother tongue speaker of the language. The data on Nyokon are far more restricted, mainly elicitation and contain only three texts.

\footnotetext{
I am very grateful to Viviane Kigno for sharing her insights and knowledge of Nyokon with me, to Emmanuel Ngue Um for bringing me into contact with her and to the Linguistics department of the University of Youndé I for offering a place to work. For the Nen data I thank Emmanuel Bakoui and Honoré Boyoleba Balehen who worked with me in the 1980s. I would also like to thank the audience of the workshop in berlin for their very valuable comments and in particular Jenneke van der Wal and Jasper de Kind.
} 
An analysis of the tense/aspect system (and the essence of tonology) can be found in Mous \& Kigno (in prep.); the phonology is covered in Lovestrand (2011); I also use an earlier source for Nyokon, Barreteau (n.d.). Nen and Nyokon are neighbours and related languages (both Mbam, 511 and 514 in the ALCAM classification). They are clearly different languages; Ethnologue (Lewis et.al. 2014) is wrong in presenting them as dialects of one language. Nyokon is heavily influenced by their other neighbours: the more distantly related Bamileke. The other languages of the Mbam subgroup of Bantu languages do not show TAM-full.object-Verb order but have some other interesting phenomena in the preverbal domain which I briefly touch upon in section 6. The Mbam languages are spoken in the Sanaga province of Cameroon. Their phonologies, in particular vowel harmony, are analysed in Boyd (in prep.).

Both languages allow full objects to either precede or follow the verb; an object preceding the verb follows subject pronoun and tense/aspect marking and I call this position the Immediately Before Verb position IBV, in order to differentiate it from the position preceding the subject and TAM marking. The position after the verb is called Immediately After Verb or IAV position. Although the two languages are neighbours, and both unique within Bantu in allowing the full object between TAM marking and the Verb, their pragmatic use of this word order option is different. Nen uses the IBV position for new information. Nyokon has IAV as the default object position for new information and IBV as an equivalent option for those tenses that allow it. The difference in default positions for objects is related to tense-limited versus unlimited options for object in IBV in Nyokon and Nen respectively. This difference in default position is also the source of the differences of functions for constructions in which both IBV and IAV are filled. Ultimately these differences between Nen and Nyokon must relate to a difference in the historical origin of the word order options.

\section{The default object position: IBV for Nen, IAV for Nyokon}

The expectation for Bantu languages is that the focussed object occurs in the position immediately after the verb (IAV). This has been argued for Aghem by Watters (1979), Hyman \& Polinsky (2009); but also for core Bantu languages in eastern and southern Africa, Makhua (van der Wal 2009); Zulu (Cheng \& Downing 2009). In Nen IBV is the position for the object when it is mentioned first in a story; it is used for the introduction of a participant as in (1). ${ }^{1}$ If the

I continue to use the phonological representation for Nen as presented in Dugast's work (1971) even though it has become evident now that the recessive and dominant version of 
introduction is a specific NP, marked by a possessive such as 'their child', this NP is still preverbal.
(1) à n-ímbìndí òn
CL1 PAST-antilope kill
(Nen)
Beginning of story: [A man went hunting, ] 'He killed an antilope.' (DC109)

But in fact the IBV position is the default position for any object in stories. Because after the introduction, when the object is discourse given, it is still preverbal.

The IBV position is also the position of the object in an answer to a question asking for the object. However, a question word asking for the object does not occur in the IBV position; instead question words are placed in pre subject position, see section 5 .

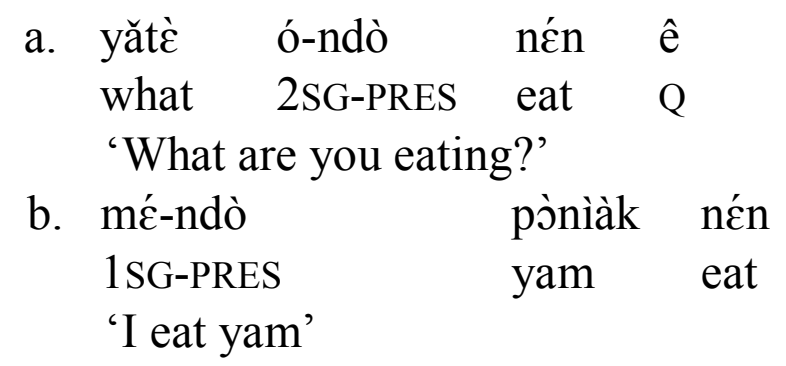

The IBV position is used when the object is predictable from the context, the expected entity.

\footnotetext{
/o/ are actually different vowels, both phonetically and phonologically, and that the /e/ in the Nen examples in this article has now completely merged with $/ \varepsilon /$. Both Nen and Nyokon are terraced level tone languages with High, Low, Downdrift and Downstep $\left({ }^{\downarrow}\right)$. I use the following abbreviations ALL for allative, APPL for applicative, CL for noun class (I use 3SG in Nyokon but CL1 in Nen subject pronouns because in Nyokon there is no class agreement in third person subject in my data); otherwise classes are marked by their standard Bantu number and without the addition CL, COMPL for complementiser, CONTR for contrast, DEM for demonstrative, EMPH for emphatic, COP for copula, D for depictive constituent, DO for direct object, FUT for future, $\mathrm{H}$ for high tone, HAB for habitual, IAV for immediately after verb, IBV for immediately before verb, INF for infinative, INJ for interjection, IO for recipient object, $\backslash \mathrm{K}$ for the verb stem shape including the marker $-a$ ' (Nyokon), LOC for locative, Mod for modifier, N for noun, NARR for narrative, NEG for negative, Num for numeral, $\mathrm{O}$ for object, OBL for oblique (preposition), $\backslash \mathrm{PA}$ for the past tense tonal shape of the verb, $\backslash \mathrm{PR}$ for the present tense tonal shape of the verb, PF for perfect, pres for progressive present tense (Nen), POSS for the possessive, PREP for preposition, PRO for pronoun, PROX for proximal, $\mathrm{R}$ for reference point in past for tense, REC for recent, REL for relative, $\mathrm{S}$ for subject, T/A for tense/aspect, $\mathrm{V}$ for verb, $\mathrm{Q}$ for final question marker.
} 
$\begin{array}{llllll}\text { (3) étyáné } & \text { wéy á-ndò } & \text { híkòkó } & \text { `súb } & \text { `é } \\ \text { who } & \text { he } & 1-P R E S & \text { drum } & \text { beat } & \text { Q }\end{array}$

(Nen)

'Who is it who beats the drum?' (DC 129)

The object in Nen is in the IBV position in negative clauses, (4) and (18b) below. $^{2}$

(4) ó sá mì̀yó sìn

2SG NEG.PAST O1SG see

(Nen)

'You did not see me.' (Dugast 1971: 179)

Thus, for Nen the object is almost always in the IBV position and when it is not, this is for very specific semantic effects which I discuss in section 3. A major difference with Nen is that Nyokon puts the object after the verb in an answer to a what?-question. The object appears in the IAV position, (5b), and the same construction is used in a corrective answer too, $(5 \mathrm{~d})$, as becomes evident in the following staged conversational sequence.
a. à
yâ ìcóó á
kà’á
têp
$2 \mathrm{SG}$ put what OBL top table
(Nyokon)

'What did you put on the table?'

b. ̀̀ yâ mìr nìpí

$1 \mathrm{SG}$ put wine palm

á

kà'á têp

'I've put palm wine on the table.'

c. à yâ mání á $2 \mathrm{SG}$ put water OBL
'Did you put water on the table?'

OBL top table

d. mbéc̀, m̀̀̀ yâ mìr nìpíi á kà'á têp no $1 \mathrm{SG}$ put wine palm OBL top table 'No, I put PALM WINE on the table.'

In fact, both the IAV and the IBV positions are used in Nyokon for the answer of a what?-question, (6a and b) below are equivalent answers to (44).

a. yé

$1: 2$ SG.POSS

'Your father killed a snake.'

kà'á têp ì

top table Q $p$
for
(44). 


\begin{tabular}{|c|c|}
\hline $\begin{array}{ll}\text { b. } & \text { ý́ } \\
1 \cdot 2 \text { SG.POSS }\end{array}$ & $\begin{array}{ll}\text { tô } & \text { yóó } \\
\text { father } & \text { snake }\end{array}$ \\
\hline
\end{tabular}

But in Nyokon certain tenses do not allow an object in IBV position. This includes all negative tenses. Where Nen predominantly has the object in IBV in negative tenses, Nyokon does not, never.

The tenses in Nyokon that do not allow the object in IBV are presented in the Table 1. The common denominator is that all the "tenses" that do not allow an IBV object involve a segmental Tense/Aspect marker. However, the narrative tense which has a segmental tense/aspect marker $p \dot{t}$ does allow for a preverbal object, (7). Those tenses that do not have a segmental tense/aspect marker show tonal changes consistent with supposing a tonal tense/aspect marker in the same position. An IBV object in those tenses is preceded by a subject pronoun. This subject pronoun is left out if the subject is a full noun. ${ }^{3}$

There is no clear semantic common denominator for tenses that allow or do not allow an object in IBV: the Past tense does but the semantically very similar Perfect does not. A historical study is needed to understand the grammaticalisation of the Nyokon tenses and how their origin can explain their syntactic qualities; the auxiliary mbiz, for example, is the verb 'to be'.

Table 1: Table of Nyokon tenses which exclude an object in IBV

\begin{tabular}{|c|c|}
\hline "tense" label & formula \\
\hline perfect & nòó $+\mathrm{V} \backslash \mathrm{PA}(\mathrm{O})$ \\
\hline present continuous & nə̆+V $\backslash \mathrm{PR}(\mathrm{O})$ \\
\hline conditional future & ná + V (O) \\
\hline Past Imperfective & S mbíá S V(\PR?) (O) \\
\hline Past Imperfective2 & $\mathrm{S}$ mbíá ku $\mathrm{V} \backslash \mathrm{PA}(\mathrm{O})$ \\
\hline Backgound & S mbíà V( (PR?) (O) \\
\hline Backgound before $\mathrm{R}$ in past & S mbìá V (O) \\
\hline Future & mə̀=Spro $\mathrm{V} \backslash \mathrm{PA}(\mathrm{O})$ \\
\hline Present Subject Focus & Compl INF-V-à' (O) \\
\hline Recent Past Subject Focus: & Compl INF-V (O) \\
\hline Perfect Subject Focus: & Compl nóò/nákú $\mathrm{V} \backslash \mathrm{PA}(\mathrm{O})$. \\
\hline Far Past Subject Focus & Compl Verb $\backslash \mathrm{PA}(\mathrm{O})$ \\
\hline Remote Past Subject Focus & Compl Verb-K $\backslash$ PA (O) \\
\hline Negative general present & $\mathrm{S}$ sí $\mathrm{V} \backslash \mathrm{H}(\mathrm{O})$ other á \\
\hline
\end{tabular}

Except in one tense, the Future; I don't know whether full noun subjects can be moved to other positions, nor whether a subject pronoun becomes needed in that case. 


\begin{tabular}{ll}
\hline “tense" label & formula \\
\hline Negative present & S nà V $(\mathrm{O})$ á nă (nòkà) \\
Negative background & S mbíá V $(\mathrm{O})$ á \\
Negative Past & S mbíá V $\backslash P A(O)$ á \\
\hline
\end{tabular}

$\begin{array}{lllll}\text { (7) ké } & \text { kìcà'ánòr } & \text { ṕ́ } & \text { vá lyès } \\ \text { 7:3SG.POSS } & \text { 7.frog } & \text { NARR } & \text { O3SG } & \text { notice } \\ \text { 'His frog notices him.' } & & & \end{array}$

(Nyokon)

The possibility for object placement depends on the "tense" in Nyokon. In tenses where there is no choice, IAV is automatically the object position. In tenses where there is a choice this choice often does not reflect any difference in meaning. For example, an object when it is mentioned first can be either in IAV or in IBV position. Sentence (8) is from the beginning of the Frog story introducing two of the main characters as objects in IAV position. ${ }^{4}$ In (9) the hole was discovered first in a narration of the same Frog story, in IBV position.

$\begin{array}{llll}\text { ò-mbíá } & \text { ygór } & \text { j̀̀̀̀p } & \text { nò kìcà'jòr } \\ \text { 3SG-PAST } & \text { possess } & \text { dog } & \text { and frog }\end{array}$
'He had a dog and a frog.'
(9) ò kyě kìỳ̀̀y ndìk
3SG INDEF hole see
'He saw a hole.'

(Nyokon)

When there is a choice in object position this is not guided by definiteness; definite and indefinite objects can occur in IBV and in IAV in Nyokon. Example (10) has an indefinite object in IBV. Definite objects can occur in IBV, e.g. an object pronoun in (7) above, even objects with a restrictive relative clause occur preverbally, (11). Also an object with a general quantifier 'all' may occur preverbally as in (12). All types of objects can occur post-verbally, and they need to in certain tenses.

$\begin{array}{llll}\text { (10) á } & \text { pìpyê } & \text { káp } & \text { vâ } \\ \text { 2SG things } & \text { buylPR } & \text { 3SG.IO } \\ \text { 'You buy him things.' } & \end{array}$

(Nyokon)

\footnotetext{
${ }^{4}$ The Frog story is a cartoon stroy commonly used for illiciting narrative text, Meyer (1969).
} 

(11) ̀̀ ándwóm àyí itá káp píí nà
1SG REC.PAST:sheep REL father buy yday eat
(Nyokon)
'I have eaten the sheep that my father bought yesterday.
(12) pí mbíá pí índín pinòm (Nyokon)
3PL PAST 3PL REC.PAST:intestines stomach
ánèm ìkìm ndìg̀̀n
$\mathrm{H}$ :animal all see
'They see all the intestines of the stomach of the animal'

There are two restictions on object placement in Nyokon for when there is a choice: Contrasted objects have to occur in IAV, see section 3, and the object is in IAV position for statements of general truth, placing 'monkey' before the verb is not natural in (13). ${ }^{5}$
(13) vàs àyí ò kîr kìtià mòó kwá kòn (Nyokon) O3SG REL 3SG bite monkey FUT fall ill
'He who eats monkey will be ill.'

In Nyokon the default and only object position is IAV for the tenses in Table 1; IAV is also the default object position for those tenses that allow an object to be in IBV with no apparent difference in meaning. In Nen the default object position is IBV and placing the object in IAV is resticted to certain pragmatic functions, a prominent one being contrast.

I have used the term Immediate After Verb for the post-verbal position and indeed the object is placed immediately after the verb and before any following obliques. There are also phonological arguments to distinguish the IAV position from post-verbal in general. Nen has a rule of High tone spread that operates between the verb and an object that is in IAV position (Mous 2003a: 287-288); Nyokon has a rule of High tone bridge between the verb and the constituent in IAV position, (Mous \& Kigno in prep).

If an object is obvious from context it need not be expressed and this includes object of usually transitive verbs such as the applicative verb in (14).
(14) nìkó ndò-nòz̀n
cold PRES-struggle:APPL
'The cold has taken [them]' (DC 303)

(Nen)

The depictive 'ill' in the second clause cannot be placed before the verb, see section 4. 


\section{Contrast and the IAV position in Nen and Nyokon}

In both Nen and Nyokon contrasted objects are placed in IAV position but there is a difference. In Nyokon the IAV position does not render the object contrastive; it can have a non-contrastive reading, but in Nen only contrasted objects (and those with a similar function) can occur in IAV. This difference correlates with the fact that in Nyokon in certain tenses objects have to be in IAV and cannot be in IBV. Contrasted objects must be in IAV position and are excluded in IBV in both languages. In the following example the semantic difference between the clause with the object in IBV (15a) and in IAV (15b) was explained as one of contrastive focus on the object in IAV position.
a. mí ìngî yò' tà'm
1SG claw leopard fear
'I fear the claws of the leopard.'
(Nyokon)
$\begin{array}{llll}\text { b. mí tà'm ìngî yò' } \\ 1 \mathrm{SG} & \text { fear claw leopard }\end{array}$
'It is the claws of the leopard that I fear, not so much other types of claws.'

Objects that are preceded by particles with functions that are similar such as $h a$ 'only' always occur in IAV position in Nen, (17).
(16) à-ná índì á mòné
CL1-PAST give CONTR money
'She/He gave MONEY.'

$\begin{array}{llll}\text { (17) mè-ná } & \text { nyá } & \text { há } & \text { mwòníf } \\ \text { 1SG-PAST } & \text { drink } & \text { only } & \text { water }\end{array}$

'I drank only water.'

In a corrective answer in Nen the negated element ('cassava') will be in IBV while the corrective (contrasted) object ('yam') is in IAV, (18).
a. ó-ndò
èsàsom
nén ê
2SG-PRES
cassava
eat $Q$

(Nen)

'Are you eating cassava?'
b. bô, mé-l'́-ndò èsàsom nén mé-ndò nén pònìàk no 1SG-NEG-PRES cassava eat 1SG-PRES eat yam 'No, I don't eat cassave, I eat YAM!'


Nyokon is similar to Nen in that objects with excluding particles can only occur in IAV position, (19); placing the object in IBV would render the utterances ungrammatical while without the contrastive particle $n$ ó these objects can occur in IBV in these sentences. The unexpectedness of 'even' in (20) invokes a contrast class (Berckmans 1993) and since 'even' seems to pattern with 'only' I prefer the term contrast to exclusivity. Also the IAV position can be used for contrast: Example (21a) is a neutral question checking the presupposition that you eat cassava; in reaction, answer (21b) corrects that presupposition and places the object after the verb for contrast.

$$
\begin{aligned}
& \text { a. ̀̀ mó ná mání } \\
& 1 \mathrm{SG} \text { drink only water } \\
& \text { 'I have drunk only water.' } \\
& \text { b. ò } \quad \text { ndìk ná pìcà'nòr } \\
& \text { 3SG seelK only frogs } \\
& \text { 'He sees only frogs.' }
\end{aligned}
$$

$$
\begin{aligned}
& \text { a. m̀ măygòrà né yò' àwár } \\
& 1 \mathrm{SG} \text { mangoes eat even ten } \\
& \text { 'I eat even ten mangos.' } \\
& \text { b. not: m̀ yò' măngòrà né. }
\end{aligned}
$$

$$
\begin{aligned}
& \text { a. á kàángè nâ'-ì } \\
& \text { 2SG cassava eat-Q } \\
& \text { 'Do you eat cassava?' } \\
& \text { b. mbéć m ń nâ' pínáá } \\
& \text { no } 1 \mathrm{SG} \text { eat yam } \\
& \text { 'No, I eat YAM.' }
\end{aligned}
$$

\subsection{Quantified objects}

In both Nen and Nyokon the IAV position is often filled with quantifiers. Nen uses the IBV position to introduce participants (first mention) in a story (if they are introduced as objects). However, whenever these participants are quantified, the object is in IAV: "he got child one" (DC 49), "the bat got children five" (DC 79), "he married wives three" (DC 87), etc. In fact, the IAV position is the most common construction if quantifiers on objects are involved. A rare example of a quantified NP in IBV position is (22). Rat is reporting to Crab; the information is old in the story and for Rat; the fact that it is all the animals is not crucial at this point. The information is given; the information is not about quantification and therefore it appears in IBV. 
(22)

$\begin{array}{lllll}\text { à } & \text { nó } & \text { mènyàmà } & \text { mì-kìm } & \text { ílì̀ } \\ \text { CL1 } & \text { REC.PAST } & 10 . \text { animals } & 10 \text {-all } & \text { let.fall }\end{array}$

(Nen)

'He has just let all animals fall.' (DC 305)

In Nyokon it is possible to have a quantified NP as object preverbally (23a); ${ }^{6}$ it can also be placed post-verbally for emphasis on the object (23b); placing just the number in IAV leaving the object noun in IBV expresses contrast on the number, as it does in Nen, (23c), see section 4 for this construction.

$$
\begin{aligned}
& \text { a. m̀ ándwôm àmò ndà' ygê } \\
& 1 \mathrm{SG} \text { sheep one give O2SG } \\
& \text { 'I have given you a/one sheep.' } \\
& \text { b. m ndà' ándwôm àmò } \\
& 1 \mathrm{SG} \text { give sheep one } \\
& \text { 'What I have given you is a/one sheep.' } \\
& \text { c. } m \text { ándwôm ndà' àmò } \\
& \text { 1SG sheep give one } \\
& \text { 'I have given you one sheep.' (not two). }
\end{aligned}
$$

What the use of quantifiers and contrast have in common is that both suppose a semantic representation in discrete entities. The IAV position seems to impose that and in Nen that leads to contrast because the default object position is IBV while in Nyokon it merely opens the possiblity of a contrast reading.

\subsection{Contrast in IBV for non-objects}

It is not possible though to equate just a position to a certain function; because there are some rare examples of a contrastive subject in IBV position in Nen, (24). My Nyokon data are insufficient to determine whether this is possible.

(24) yə̌múnókó n-táyé ‘fám ò mím chameleon PAST-him leave LOC house

'The chameleon, he, he left the house (while the other went to bed).' (DC 71).

6 I have no examples with a number other than 'one' though, and 'one' is used for indefinite marking too. 


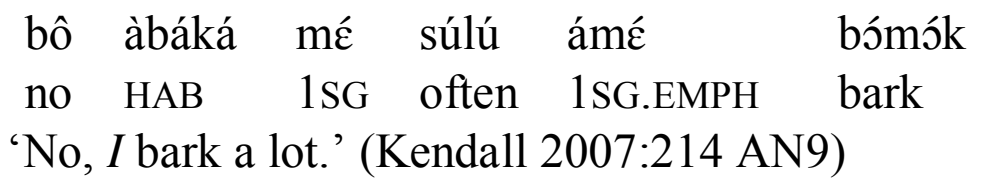

In Nen, an oblique nominal phrase like 'this moment' can occur in IBV position as it does in (26) where it refers to the crucial moment in the story that Rat had dealt with all other animals. What is expressed is emphasis maybe even contrast, as against after all the beatings of animals, now Rat went to the last opponent.

$$
\begin{aligned}
& \text { měló ná y’ íkúlí ákán á nìnà? } \\
& \text { rat PAST 9:DEM.PROX time go PREP crab }
\end{aligned}
$$

'Then the rat went to the crab.' (DC 305)

\section{$4 \quad$ IBV+IAV and secondary predication}

It is possible for the object to be split with one part before the verb and the second part after the verb. The post-verbal consituent is often a numeral. I argue that this construction involves two constituents and not one. I consider these constructions of both IBV and IAV filled to be instantiations or extensions of secondary predication constructions. There are again differences across Nen and Nyokon in the properties of the construction because the basic secondary predication construction is different: X Verb Y in Nyokon and Verb X Y in Nen, while in Nen the object noun can freely move to IBV resulting in a IBV+V+IAV construction.

In Nen the modifier that is in IAV position is interpreted as constrastive when compared to a construction with noun plus modifier in preverbal IBV position, (27).

$\begin{array}{llllll}\text { mèná } & \text { ìmítá } & \text { yè } & \text { mwònífí índì mè-nèn } \\ \text { 1SG:PAST 9:calabash } & \text { 9:of } & 6: \text { water } & \text { give } & \text { 9-big } \\ \text { ò hèlóbátò } & & & & \\ \text { LOC } 19: \text { child } & & & & \end{array}$

(Nen)

'I gave the BIG water calabash to the child.'

These properties are also valid for Nyokon. In (28) the modifier is in IAV position and receives contrast. The same is true for (29) where the modifier is the numeral 'one'.
(28)
m̀ ándwôm
ndà'
fì'
1SG REC.PAST:sheep give black
(Nyokon)
'I have given a black sheep (i.e. not a white one).' 
There is a difference between Nen and Nyokon here: In Nyokon a $\mathrm{N}+\mathrm{V}+\mathrm{Num}$ construction renders the numeral contrastive as in (29) above, and see also (23). In Nen, however, the split construction with a numeral after the verb seems to be pragmatically equivalent to one with head noun plus numeral in IAV position. For example, in the story "The man and his children" (DC 387-396 repeated as "Orphan" in Kendall 2007: 186-213) the same episode is repeated with the same sentences apart from this difference in word order, $(30 \mathrm{~b})$ which is a repetition of (30a). ${ }^{7}$ In Nen a constituent with a number cannot occur in IBV.

$$
\begin{array}{llll}
\text { a. à } & \text { ná-`'ká-níbá } & \text { híkúmúkúmú } & \text { hímòtì } \\
\text { CL1 } & \text { PAST-ALL-meet } & \text { old.person } & \text { one }
\end{array}
$$

'He came upon an old woman.' (Kendall 2007:187, OR 19= DC 387)
b. à ná-`'ká híkúmúkúmú níbà hímòtì
CL1 PAST-ALL old.person meet one
'He came upon an old woman.' (Kendall 2007:202, OR $161=$ DC 391)

I link the functions of contrast and the use of a number as modifier to the fact that both imply the semantic operation of viewing the range of referents that the object evokes as organised in discrete units. Number expression requires such a view and contrast singles one out.

In certain sentences it is not possible to separate the object noun phrase in a pre-verbal and a post-verbal part. This is never possible for a genitive phrase within a noun phrase. Thus 'of the chief' in (31) cannot be moved to the IAV position in Nen. In Nyokon, the genitive phrase 'of the leopard' in (15) above cannot be put in IAV position with the head, 'claws', in IBV position; the only possible interpretation of such a clause is that 'the leopard' appears after an intonation break and as an addressee, no longer as the possessor of the claws.

The equivalent of Nen example (27) was not accepted in Nyokon because the object of giving would be conceived not as a calabash that is simply big in size but as specific (big) type of calabash and such a division in types of calabashes to size does not exist in the Nyokon lexicon. It does for 'yam' for which there are big and small types and hence example (21b) above is acceptable. Likewise, there are white and black types of sheep, (28). Thus, the

\footnotetext{
7 It is possible that the split construction in (30b) is chosen because the sentence continues with an infinitival constituent while this information is in a separate clause in (30a).
} 
constituent in the IAV position cannot be parsed as a dependent modifier of the constituent in IAV. It must be parsed as a separate constituent but this constituent must be interpreted as having the same referent as the constituent in IBV position not modifying it in a gradual manner but singling out a discrete specimen.

a. mèná òndómbá wú mùnònì sì̀kìn
1SG:PAST sheep of chief
'I saw the sheep of the chief.'

b. * mena ondəmba siəkin wu munəni

Thus, the "split" construction is not "split" but consists of a construction with two constituents, one in IBV and one in IAV, that share one referent. This is in fact a secondary predicate or depictive construction (Schultze-Berndt and Himmelmann 2004). Typical depictive secondary predicate constructions involving the object for Nyokon indeed make use of such a construction of object in IBV and depiction in IAV, (32).
a. tòy yòó ngà' Kìnò
1PL child call $\mathrm{K}$
'We call the child Kigno.'
b. pí yíp tôsk púm
3PL house paint white
'They paint the house white.'
c. píyíòy yé yís yímk pilénpilén
8.thoughts 9:3SG.POSS 9.eyes make $\backslash K \backslash P R$ tear
'Sadness makes his eyes wet.'

(Nyokon)

In Nen, however, a typical secondary predicate involving an object is constructed by placing two NPs after the verb as in (33).
a-na-somba
mukoli
ikut
CL1-PAST-cut
rope
piece

(Nen)

'She/He cut the rope in pieces.'

The constituent in IAV does not only refer to objects in IBV. As is common with secondary predicate constructions, the depictive can have wider scope. In (34) the IAV numeral agrees with and refers to the subject. ${ }^{8}$

8 In the second example, from Nyokon, the numeral may not be exactly in IAV. 


$$
\begin{aligned}
& \text { a. ă mwósé `ná-tómbá màlánù? } \\
& \text { ? 6:days PAST-pass 6:five } \\
& \text { 'Five days passed.' (DC:403) }
\end{aligned}
$$
b. nyàás nà
pàá àyí pí pîn pâ pá-fòò twin COP 2.child REL 3PL born 3PL 2-two 'Twins are children that are born two.'

An adjective in the IAV position can be interpreted as having scope over the entire clause rather than being equated to the IBV phrase, as in (35) where the adjective 'big' can signify 'a lot' modifying the whole VP in interpretation (ii) rather than 'big', singling out a big branch in interpretation (i).

$\begin{array}{llll}\text { mè-ndò } & \text { mòkàsà } & \text { sìnà } & \text { mò-yèn } \\ \text { 1SG-PRES } & \text { 3:branch } & \text { see } & \text { 3-big }\end{array}$

i) 'I see a BIG branch'; ii) 'I see the branch too much.'

I have sugested that the IAV position is needed for the interpretation of the object as being represented as discrete and hence countable and susceptible for constrast reading. This is reinforced by the secondary predicate construction. In Nyokon the secondary predicate construction has the depictive in IAV and that consituent shares the referent of the object in IBV. Therefore a numeral in IAV will be interpreted as modifying the noun object in IBV, and as contrastive. An adjective in IAV in the secondary predicate construction will be interpreted as identifying a discrete subtype of the object in the IBV; hence the big type of yam in (21b) or the black type of sheep in (28). Schultze-Berndt (2002) observes that restrictive particles such as 'just' and 'only' are often combined with depictives to exclude other possible events from the one expressed by the depictive sub-event.

There is additional evidence that the construction with both IBV and IAV filled acts as a secondary predicate construction. In both Nen and Nyokon it is possible to have one part of a coordinated noun phrase in IBV and the second part, the PP with the coordinating preposition, in IAV position. This construction expresses that the two constituents are together. If the addition is constructed as a depictive both entities of the coordination need to refer to the same referent and hence they have to constitute one event and the two coordinants have to be together. The equivalent sentence with a coordinated NP 
in IBV is neutral and does not insist on the fact that the two entities are together. ${ }^{9}$

$$
\begin{array}{lllllll}
\text { mèná } & \text { c̀ndómbá } & \text { sì̀kíná } & \text { ná } & \text { mì̀̀̀ } & \text { ò } & \text { nyònì } \\
\text { 1SG:PAST } & \text { sheep } & \text { see } & \text { and } & \text { chickens } & \text { LOC } & \text { market }
\end{array}
$$

'I saw sheep together with chicken on the market.'
a. mú ípún ndìk nò ìndwómá 1SG PA:goats see and sheep:F
'I saw the goats and the sheep.'
b. mú ípún nò ìndwóm ndìk
1SG PA:goats and sheep see
'I saw the goats and the sheep.'

The element in IAV position is a separate consituent for both Nen and Nyokon. For both, Nyokon and Nen, the IAV position involves discrete entitities, selecting one, equating to the IBV constituent if present. In Nen, the N+Num in $\mathrm{IAV}$ is equivalent to the $\mathrm{N} \mathrm{V}$ Num construction and a construction with two constituents in IAV position is interpreted as a secondary predicate construction, including the V N Num construction. Since the default position for the object in Nen is IBV such $\mathrm{N}$ of the V N Num construction can move without a semantic effect to IBV position if it is an object.

There is one instance of the construction with both IBV and IAV filled which is possibly only motivated by reasons of information processing: Relative clauses to the object head noun are sometimes placed after the verb to avoid a preverbal object that is too heavy, (38).

\begin{tabular}{|c|c|c|c|c|c|}
\hline mé-ndò & mòná & òwá & a-nà & & \\
\hline 1SG-PRES & child & $\begin{array}{c}\text { REL } \\
\text { Mòmóó }\end{array}$ & CL1-PAST & & \\
\hline $\begin{array}{l}\text { mòníá } \\
\text { 6.money }\end{array}$ & $\begin{array}{l}\text { má } \\
6: \text { of }\end{array}$ & $\begin{array}{l}\text { wàmì́ } \\
1: 1 \mathrm{SG} . P O S S\end{array}$ & $\begin{array}{l}\text { mùníǹ̀ } \\
\text { brother }\end{array}$ & $\begin{array}{l}\text { ôb } \\
\text { steal }\end{array}$ & $\begin{array}{l}\text { màny } \\
\text { know }\end{array}$ \\
\hline
\end{tabular}

Sentence (39) show that the relative clause to the object head noun can either precede the verb (39b) or follow the verb (39a) in IAV position with the head

$9 \quad$ In Nyokon this construction requires a clause final marker $a$ which is no longer needed if the coordinated noun phrase is formed as PP, pŕ indwôm, with the preposition $p \hat{x}$ 'with' instead of the coordinater $n$ ’े. 
noun still in IBV. Interestingly, in that construction the relative pronoun can no longer be left out. ${ }^{10}$

$$
\begin{array}{llllllll}
\text { a. mì } & \text { ándwóm nà' àyí ìtâ } & \text { káp pí } & \text { (Nyokon) } \\
1 \mathrm{SG} & \text { sheep } & \text { eat } & \text { REL father buy yday } &
\end{array}
$$

'I have eaten the sheep that my father had bought yesterday.'

b. mì ándwóm (àyí) ìtô káp píi jà'
$1 \mathrm{SG}$ sheep (REL) father buy yday eat
'I have eaten the sheep that my father had bought yesterday.'

\section{The clause initial position}

The clause initial position is used for topics. There is a clear intonation break after this topic position which is in Nen often realised by a glottal stop. In Nen, all kinds of noun phrases can occur in the topic position position: objects, locative phrases (complement or not), and adjuncts. Such topics are actually quite rare in texts. What we find in texts occasionally as topics are time adverbials such as 'at that time' (40), 'once upon a time' (41) in the topic position. Objects can occur in topic position too, (42).

(40) ò

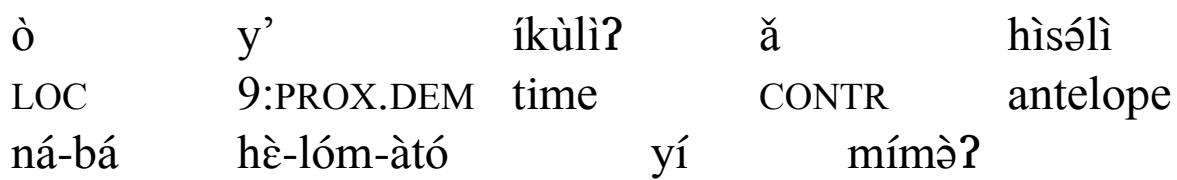

(Nen)

ná-bá hè-lóm-àtó yí mímò?

PAST-be 19-send-part of house

'At that time, it was antelope who was his servant.' (Kendall 2007:219 AN55)

(41) ùósé bó-mòtè? mènyàmà ná-kòtàkáná

14.day 14-one animals PAST-get.together

(Nen)

'One day the animals got together' (Kendall 2007:214 AN1)

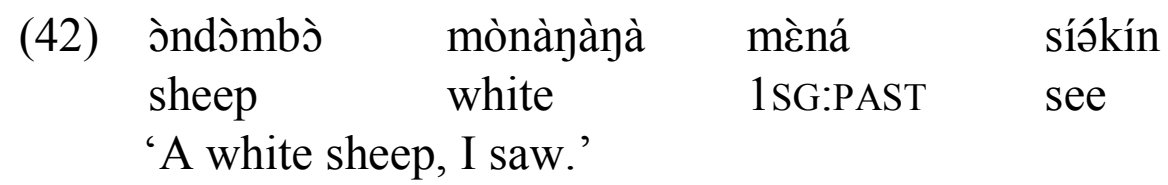

(Nen)

Question words are preferred to be put in pre-subject position in both languages. Hamlaoui and Makasso (2011:50-51) report for neighbouring Basaa too that the question words tend to be fronted.

10 Which is an extra indication that the IAV string is a separate constituent 
(43)
a. yătè ó-ndò nén ê what 2SG-PRES eat Q
'What are you eating?'
b. ícóó ò yín ít what 3SG steal Q
'What did he steal?'

(Nyokon)

The question word asking for the object can occur postverbally, (44a), but mostly occurs sentence initially, (44b). Question word in the preverbal object position is either an echo question or sounds childish, (44c).
a. yé
tô nóò yóó
ícóó
1:2SG.POSS father PF kill:PAST what
'What did your father kill?'
b. ìcóó yé tô nóò yóó
what 1:2SG.POSS father PF kill:PAST
'What did your father kill?'
c. *? yé tâ nóò ìcóó yóó
1:2SG.POSS father PF what kill:PAST
'Your father killed what?'

(Nyokon)

In the pre subject position we find apart from question words, also complementisers like $m b a ̀$ 'then, thus', ákà 'if', $k k \grave{\varepsilon}$ 'when', $h a$ ' 'then' also when an interjection procedes $(45,46)$. I have not investigated how many and which pre-subject positions need to be distinguished.
(45) êy êy
éyànè
mì̀yó
bétòtò
kòndònàk
INJ INJ
who
$1 \mathrm{SG}$
buti.fruit remove
(Nen)
'Hey, hey Who will take the buti fruit off me?' (Kendall 2007:191 OR56)
(46) wêع hóní
hí
hènókónókó
INJ where
nó-húl
19:PROX.DEM
té
PAST-come.from
Q
'Hey! Where did this young man come from?' (Kendall 2007:194 OR83) 
(47) bó búsî̀? ábá mé ndò-fìn

of first if $1 \mathrm{SG}$ PRES-enter

ò nèmànènà

LOC leadership

'But first, if I go into leadership, ...' (Kendall 2007:215 AN16)

\section{The preverbal domain in Nen and some thoughts on history}

In Nen, and many other Mbam languages, the subject agreement and tense/aspect markers are separate words and not prefixes to the verb. The only true prefix to the verb is the "passive" or middle prefix bé-. ${ }^{11}$ Nen has full ATR vowel harmony and that provides clues for word boundaries. From the optional or compulsory nature of harmony we can deduct that the slots in Table 1 are indeed separate words (except for the middle prefix). The optional harmony shows that there is a strong tendency to cliticization of non-lexical morphemes to the right, Boyd (in prep). The subject and tense/aspect marker are always adjacent; if the subject is a full noun there is no agreeing subject marker. The structure of the preverbal domain in Nen is summarised in the following table.

Table 2: The preverbal domain of Nen

\begin{tabular}{|c|c|c|c|c|c|c|c|}
\hline Topic & PreS & $\mathrm{S}$ & $\mathrm{T} / \mathrm{A}$ & $\mathrm{adv}$ & $\begin{array}{l}\text { IO+DO } \\
\mathrm{S}\end{array}$ & $\begin{array}{l}\text { Directio } \\
\text { nal }\end{array}$ & $\begin{array}{ll}\text { Mid } & \mathrm{V} \\
\text { dle } & \\
\end{array}$ \\
\hline $\begin{array}{l}\text { topics } \\
\text { inter- } \\
\text { jec- } \\
\text { tions }\end{array}$ & $\begin{array}{l}\text { ques- } \\
\text { tion } \\
\text { words } \\
\text { compl } \\
\text { ementi } \\
\text { sers: } \\
\text { then, } \\
\text { when, } \\
\text { if, }\end{array}$ & $\begin{array}{l}\text { nominal } \\
\text { subject } \\
\text { pronomi } \\
\text { nal } \\
\text { subject }\end{array}$ & $\begin{array}{l}\text { ndò } \\
\text { PRES, } \\
\text { ná PAST } \\
\text { etc. }\end{array}$ & $\begin{array}{l}\text { quickly } \\
\text { often } \\
\text { etc., } \\
\text { time } \\
\text { adver- } \\
\text { bials }\end{array}$ & $\begin{array}{l}\text { nominal } \\
\text { IO, DO, S } \\
\text { (emphatic) } \\
\text { independent } \\
\text { pronoun } \\
\text { IO, DO, S }\end{array}$ & $\begin{array}{l}\text { allative, } \\
\text { ventive } \\
\text { clitics }\end{array}$ & $b e^{-}$ \\
\hline
\end{tabular}

The IBV position in Nen can have two constituents. Both an Indirect Object and a Direct object can be in IBV in that order in Nen, (49). In Nyokon, it is impossible for an Indirect Object to be in IBV position. In Nen we can have verbal adverbs such as hútú 'quickly', súlú 'often' in IBV position; also in addition to an object, (48). ${ }^{12}$

11 See Mous (2008) for a discussion of the middle prefix.

12 I do not know whether that is possible for Nyokon; I have no such examples. 
'She/He gave them to me' NOT: 'She/He gave me to them.'

Grammaticalisation of verbs and adverbs into a verbal tense/aspect/mood prefix in the verb word is a common process in Bantu languages. Only in Nyokon and Nen does this lead to the possibility of having a full noun object between the (new) TAM marker and the verb stem. In the rest of Bantu the frame of the verb slots is rigid enough to keep the object out of the verb despite the fact that the emergence of disyllabic TAM markers is not unheard of, for example, Ma'á/Mbugu has the TAM prefix manga which stills functions as an independent adverb 'quickly', é-mangá-kúru 1-SPEED-cultivate 'he hurries to cultivate' (Mous 2003b:151). Most Mbam languages show evidence of isolating elements in the prestem domain but only for Nen and Nyokon this opened the possibility for full objects in the position before the verb stem. Further historical study of Mbam Bantu must reveal whether this isolating nature of the pre-stem elements is an innovation or a property inherited from pre-Bantu and leaving the development of a rigid verb word with slots as a non-Mbam Bantu innovation.

\section{$7 \quad$ Summary and conclusions}

The properties of objects and word order are summarised in the following tables. Table 3 displays how different pragmatic functions are realised with respect to objects. I have left out the clause initial positions as they are given in Table 2 above. Table 4 provides the interpretive options for the various word order possibilities, again Nen and Nyokon compared.

Table 3: Expression in Nyokon and Nen for Objects

\begin{tabular}{lll}
\hline dimension & Nyokon & Nen \\
\hline first mention O & IBV & IBV \\
answer to what? & IAV & IBV \\
contrastive O & IAV & IAV (+ marker) \\
& $*$ IBV & *IBV \\
quantified O & O V Num & O V Num \\
\hline
\end{tabular}




\begin{tabular}{lll}
\hline & V O Num & $\begin{array}{l}\text { V O Num } \\
* \text { O Num V }\end{array}$ \\
negation & IAV & IBV \\
& $*$ IBV & (IAV) rare \\
position 'what?' & preS, IAV, *IBV & preS \\
locative object & V LOC & V LOC \\
depictive qual & O V D & V O D \\
\hline
\end{tabular}

Table 4: Interpretation in Nyokon and Nen of word order options for objects

\begin{tabular}{|c|c|c|}
\hline dimension & Nyokon & Nen \\
\hline$O$ in IBV & $\begin{array}{l}\text { only possible certain } \\
\text { tenses } \\
\text { only DO } \\
\text { not in negative clause } \\
\text { not contrast } \\
\text { unspecific }\end{array}$ & $\begin{array}{l}\text { always possible } \\
\text { IO +DO } \\
\text { default: indef, def, first mention, } \\
\text { answer to what? }\end{array}$ \\
\hline$S$ in IBV & $?$ & contrast \\
\hline $\begin{array}{l}\text { O in IAV } \\
\text { (IBV empty) }\end{array}$ & $\begin{array}{l}\text { i. default: answer to } \\
\text { what? } \\
\text { ii. contrast } \\
\text { general statement }\end{array}$ & contrast \\
\hline N Num V & neutral & -- (does not occur) \\
\hline N V Num & $\begin{array}{l}\text { i. neutral } \\
\text { ii. contrast on Num }\end{array}$ & $\begin{array}{l}\text { neutral } \\
\text { N V Num } \sim \text { V N Num }\end{array}$ \\
\hline $\begin{array}{l}\text { V N Num } \\
\text { N V + N } \\
\text { N + N V } \\
\text { N V Mod }\end{array}$ & $\begin{array}{l}\text { emphasis on } \mathrm{N} \\
\text { both together } \\
\text { neutral } \\
\text { modifier cannot be } \\
\text { genitive }\end{array}$ & $\begin{array}{l}\text { neutral } \\
\text { both together } \\
\text { neutral } \\
\text { modifier cannot be genitive }\end{array}$ \\
\hline & $\begin{array}{l}\text { modifier expresses } \\
\text { discrete option } \& \\
\text { contrast on Mod }\end{array}$ & $\begin{array}{l}\text { i. contrast on Mod } \\
\text { ii Mod has scope over clause }\end{array}$ \\
\hline $\begin{array}{l}\text { N Mod V } \\
N \text { V X }\end{array}$ & $\begin{array}{l}\text { neutral } \\
\mathrm{N}=\mathrm{X} \text { (depictive/sec pred) }\end{array}$ & neutral \\
\hline $\begin{array}{l}\text { V N X } \\
\text { S - V Num } \\
S_{\mathbf{i}} \text { T/A } \mathbf{s}_{\mathbf{i}} \text { V X }\end{array}$ & Num refers to $S$ & $\begin{array}{l}\mathrm{N}=\mathrm{X} \text { (depictive/sec pred) } \\
\text { Num refers to } \mathrm{S} \\
\text { contrast on } \mathrm{S}\end{array}$ \\
\hline
\end{tabular}


In Nen IBV is the default position of object but in Nyokon this is IAV. This positional difference is reflected in where objects occur in negative clauses. In Nen the IAV position is reserved for contrast; in Nyokon a contrast interpretation is possible but a neutral or selective focus interpretation is equally posisble. This difference is linked to the fact that in Nen the restrictions on where objects can be placed depend only on the properties of the objects while in Nyokon this depends first of all on the "tense" that is used. The IAV position allows for an interpretation in which the constituent in this position is viewed as a discrete unit that is quantified or contrasted, particularly when it is the depictive part of a secondary predicate construction with the other constituent with the shared referent is an object preceding the verb.

Any element in IAV is a constituent that is not part of the IBV constituent. But the constituent in IAV has the consituent in IBV in its semantic scope. In Nyokon any construction with IBV and IAV filled is in fact a secondary predicate type of construction in which both constituents share a referent. In Nen the secondary predication construction is formed by two consituents in the IAV position but the first one being the object can be moved into IBV position without a semantic effect as that is the default object position.

Clause initial (topic) position is used for topics. Question words are in a pre-subject position. Movement of subject to IBV invokes comparison with other comparable possibilities and hence contrast. ${ }^{13}$

\section{References}

Barreteau, Daniel n.d. Questionnaire linguistique ALCAM: Nyokon.

Berckmans, Paul (1993). The quantifier theory of even. Linguistics and Philosophy 16(6): 589-611.

Boyd, Ginger in prep. $\mathrm{PhD}$ thesis on vowel harmony in Mbam languages, Leiden University.

Cheng, Lisa and Laura J. Downing (2009). Where's the topic in Zulu? In: Helen de Hoop \& G. van Bergen (eds.). Special issue on Topics Cross-linguistically, The Linguistic Review 26, 2/3, 207-238.

Dugast, Idelette (1955). Monographie de la tribu des Ndiki (Bancn du Cameroun), vol.I: Vie matérielle (Travaux et mémoires de l'Institut de'ethnologie, 58.) Paris: Musée de l'Homme.

Dugast, Idelette (1960). Monographie de la tribu des Ndiki (Bancn du Cameroun), vol.II: Vie Sociale et familiale (Travaux et mémoires de l'Institut de'ethnologie, 63.) Paris: Musée de l'Homme.

Dugast, Idelette (1967). Lexique de la langue Tunen (Parler des Banen du Sud-Quest du Cameroun) Paris: Éditions Klincksieck.

13 This can be compared to movement of modifier to pre-nominal position, see Mous (1997). 
Dugast, Idelette (1971). Grammaire du Tunen (Langues et Littératures de l'Afrique Noire, 8.) Paris: Éditions Klincksieck.

Dugast, Idelette (1975). Contes, proverbes et devinettes des Banen (Sud-Ouest du Cameroun) (Langues et Civilisations Tradition Orale, 12.) Paris: SELAF.

Hamlaoui, Fatima and Emmanuel-Moselly Makasso (2011). Bàsàa Wh-questions and Prosodic Structuring. ZAS Papers in Linguistics 55:47-63

Hyman, Larry \& Maria Polinsky (2009). Focus in Aghem. In: Malte Zimmermann \& C. Fery Information Structure: Theoretical, Typological, And Experimental Perspectives. Oxford: Oxford University Press; pp. 206-233

Kendall, Mark Isaac (2007). Participant reference in Tunen narrative discourse. MA thesis Graduate Institute of Applied Linguistics, Dallas, Texas.

Lewis, M. Paul, Gary F. Simons, and Charles D. Fennig (eds.). (2014). Ethnologue: Languages of the World, Seventeenth edition. Dallas, Texas: SIL International. Online version: http://www.ethnologue.com

Lovestrand, Joseph (2011). Notes on Nyokon phonology (Bantu A.45, Cameroon). Yaounde: SIL Cameroon.

Meyer, Mercer (1969). Frog, where are you ? New York: Dial books for young readers.

Mous, Maarten (1997). "The position of the Object in Tunen" In Object Positions in BenueKwa, (ed.). by Rose-Marie Déchaine en Victor Manfredi, pp. 123-137. Den Haag: Holland Academic Graphics.

Mous, Maarten (2003a).“Nen”. In The Bantu languages, edited by Derek Nurse and Gérard Philippson, pp. 283-306. London: Routledge.

Mous, Maarten (2003b). The Making of a Mixed Language: The Case of Ma'a/Mbugu Amsterdam: John Benjamins.

Mous, Maarten (2005). "The innovative character of Object - Verb word order in Nen (Bantu A44, Cameroon)" In Studies in African comparative Linguistics with special focus on Bantu and Mande; essays in honour of Y. Bastin and C. Grégoire, ed. by Koen Bostoen and Jacky Maniacky. Tervuren: MRAC. pp. 411-424.

Mous, Maarten (2008). "Voice in Tunen: The so-called passive prefix bé-" In Evidence and Counter-evidence: Festschrift Frederik Kortlandt volume 2, ed. by Alexander Lubotsky, Jos Schaeken, Jeroen Wiedenhof, pp. 303-312. New York: Rodopi.

Mous, Maarten \& Viviane Kigno In prep. The tenses of Nyokon (nìnò's, Bantu A45, Cameroon).

Schultze-Berndt, Eva (2002). Grammaticalized restrictive particles on adverbials and secondary predicates: evidence from Australian languages. Australian Journal of Linguistics 22(1): 231-264.

Schultze-Berndt, Eva and Nikolaus P. Himmelmann (2004). Depictive secondary predicates in crosslinguistic perspective. Linguistic Typology 8:59-131

van der Wal, Jenneke (2009). Word order and information structure in Makhuwa-Enahara. Utrecht: LOT. (Ph.D. dissertation, Leiden University). 
Watters, John R. (1979). Focus in Aghem: a study of its formal correlates and typology. In Larry M. Hyman (ed.). Aghem grammatical structure. (Southern California Occasional Papers in Linguistics 7.), pp. 137-197. Los Angeles: University of Southern California.

Wilhelm, M. (1973). Le Mbam central. Colloques Internationaux du CNRS 551. Contribution de la recherche ethnologique à l'histoire des civilisations de Cameroun, pp. 437-452. 